\title{
PEMANFAATAN AIR TANAH JAKARTA
}

\author{
Samsuhadi \\ Pusat Teknologi Lingkungan, Deputi TPSA, BPP Teknologi \\ JI. MH. Thamrin No. 8 Jakarta Pusat
}

\begin{abstract}
The Jakarta groundwater is one of the water resources in which people rely on it in great deal. With the limitation of the Water Supply Company to serve its user, groundwater becomes very valuable and dependable resource. The magnitude of extraction reaches out above it's save yield. In the year of 2002 about 1230 to 1590 millions cubic meters water were accumulated from precipitation. Approximately of 1027 million cubic meters each year about to be consumed by the people of Jakarta. The groundwater consumption tend to increase while the land capability to absorb groundwater decreasing as the land development expanding. Hidrologically the hydraulic conductivity of the Jakarta groundwater aquifer system is very low, so that the groundwater flowrate from the south region of Jakarta basin is also low. With the magnitude of extraction's very havily, the cone of depression incident has been occurring in the north Jakarta region. Along with this incident, a land subsidence was also occurring in the neighboring area. To overcome these problems, the assessment of the artificial recharge to the Jakarta aquifer particularly at the critical locations has been done. Schemes of the artificial recharges were simulated. Locations and magnitudes of these schemes were recommended to prevent further depression and saltwater intrusions.
\end{abstract}

Key words : groundwater, aquifer, basin Jakarta, simulation, artificial recharge.

\section{Pendahuluan}

Seperti sudah kita sadari bersama bahwa air tanah Jakarta menjadi tumpuan harapan warga Jakarta dalam pemenuhan kebutuhan air bersih. Hal ini dimungkinkan karena sistem penyediaan air bersih yang sudah ada tidak menjangkau semua warganya (diperkirakan hanya 38\% warga Jakarta yang dapat menikmatinya, sehingga pilihan sumber lain yang dapat diharapkan adalah air tanah, karena air sungai yang mengalir ke Jakarta juga tidak layak untuk dimanfaatkan karena permasalahan kualitas yang sangat buruk.

Karena sebagian besar warga Jakarta memanfaatkan air tanah sebagai sumber air bersih, terjadilah ekstraksi air tanah secara besar-besaran dan hampir tanpa terkendali. Akibat dari ekstraksi air tanah yang besar ini, sistem air tanah menanggung beban yang sangat berat. Aliran imbuhan air tanah yang seharusnya didapat dari area resapan yang berasal dari selatan Jakarta (yang mengalir melalui akuifer dan menjadi air tanah artesis) maupun yang berasal dari resapan lokal (dari hujan lokal yang kelak menjadi air tanah dangkal) tidak dapat mengimbangi tingkat pengambilan air tanah yang sangat tinggi.

Penggunaan air tanah sudah melebihi kemampuan alamnya untuk mengembalikan keseimbangannya secara mandiri (homoeostatis). Akibat dari pemakaian yang tidak dikendalikan, terjadi penurunan yang luar biasa pada muka air tanah akuifer dangkal maupun tekanan akuifer artesis. Insiden penurunan muka air tanah dan tinggi tekan ini terutama sangat terasa di kawasan utara Jakarta. Selain penurunan muka air tanah, insiden penurunan muka tanah juga terjadi di kawasan yang sama.

Walaupun penurunan muka air tanah dangkal atau penurunan tinggi tekan air tanah artesis bukan merupakan penyebab langsung turunnya muka tanah, akan tetapi rongga antar butir tanah yang kosong (akibat turunnya muka air tanah) dapat memicu pemadatan tanah (kompaksi). Dari aspek lain, walaupun tidak seburuk insiden penurunan muka tanah dan penurunan muka air tanah, intrusi air laut di kawasan pesisir masih menjadi masalah yang serius. Perambatan intrusi air laut khususnya dikawasan pantai semakin meningkat ${ }^{1)}$.

Dengan terjadinya insiden seperti diatas, pemanfaatan air tanah terancam tidak dapat dipertahankan keberlanjutannya, karena kemampuan sistem untuk memenuhi kebutuhan warganya semakin menurun dan kemampuan sistem untuk memperoleh kesimbangan dirinya juga tidak pernah tercapai.

\section{Tujuan Pembuatan Paper}

Dengan adanya permasalahan yang terjadi pada sistem air tanah Jakarta terutama pada akufer air tanah dalam, yang terjadi defisit yang sangat besar antara pemanfaatan dengan suplesi (pemanfaatan air tanah yang tinggi sementara suplesi air tanah berlangsung sangat lambat), solusinya adalah mengembalikan 
kondisinya sehingga secara ekologis tercapai keseimbangan dan pemanfaatan air tanah dapat berkelanjutan. Penerapan Imbuhan buatan pada air tanah dalam (air tanah artesis) adalah salah satu opsi skema untuk menambah ketersediaan air tanah. Jika keseimbangan dapat dicapai, dampak yang lain adalah dapat mencegah terjadinya intrusi air laut yang lebih jauh.

\section{Kondisi Hidrogeologis Sistem Air Tanah Jakarta}

Secara fisik sumberdaya air tanah Jakarta tidak dibatasi oleh wilayah administrasi, akan tetapi lebih dibatasi oleh wilayah aliran air tanah, yang terminologi umumnya disebut basin. Basin Air tanah Jakarta ini mempunyai area yang sangat luas yang secara fisik mengikuti 14
Daerah Aliran Sungai yang mengalir kekawasan Jakarta dan sekitarnya (Gambar 1).

Kalau ditelusuri dari hulu, aliran air tanah dimulai dari lereng gunung Pangrango, gunung Gede dan gunung Salak, gunung Halimun dimana didaerah hulu ini air tanah mulai diterima oleh permukaan tanah dan kemudian meresap kedalam tanah, kemudian setelah meresap kedalam tanah, oleh akuifer dialirkannya kearah hilir sebelah selatan menjadi air tanah dangkal (air tanah bebas) dan air tanah dalam (air tanah tertekan, atau sering disebut juga air tanah artesis).

Selanjutnya sesampainya dikawasan utara, yang diatasnya meliputi wilayah Kabupaten Bogor, kota Depok, sebagian Kabupaten dan kota Tangerang, sebagian wilayah kabupaten dan kota Bekasi dan paling
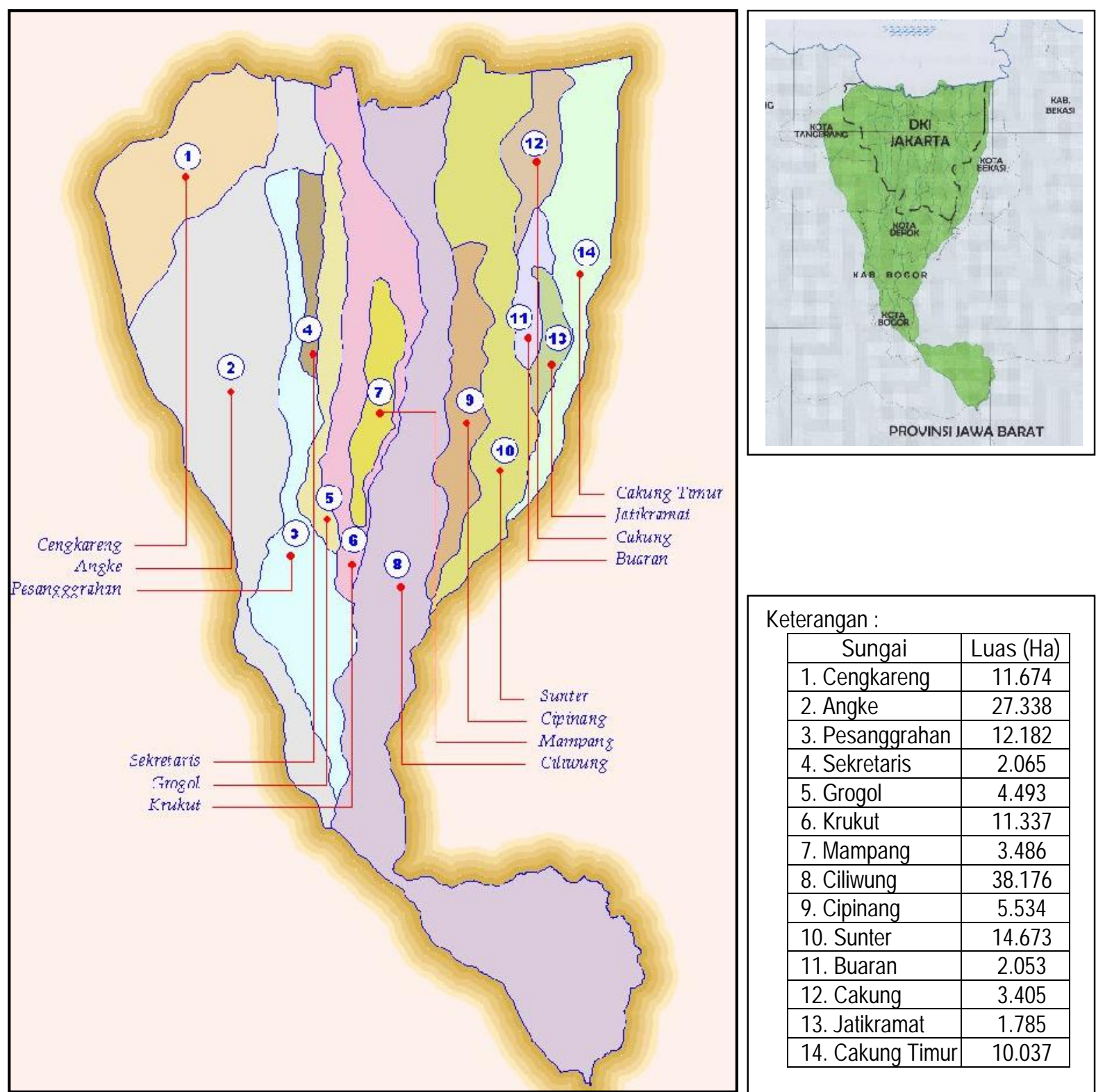

Keterangan :

\begin{tabular}{|l|c|}
\hline \multicolumn{1}{|c|}{ Sungai } & Luas (Ha) \\
\hline 1. Cengkareng & 11.674 \\
\hline 2. Angke & 27.338 \\
\hline 3. Pesanggrahan & 12.182 \\
\hline 4. Sekretaris & 2.065 \\
\hline 5. Grogol & 4.493 \\
\hline 6. Krukut & 11.337 \\
\hline 7. Mampang & 3.486 \\
\hline 8. Ciliwung & 38.176 \\
\hline 9. Cipinang & 5.534 \\
\hline 10. Sunter & 14.673 \\
\hline 11. Buaran & 2.053 \\
\hline 12. Cakung & 3.405 \\
\hline 13. Jatikramat & 1.785 \\
\hline 14. Cakung Timur & 10.037 \\
\hline
\end{tabular}

Gambar 1. Pembagian DAS sungai sungai yang mengalir ke kawasan Jakarta (Tambunan, 2005) 
besar adalah Propinsi DKI Jakarta, lapisan tanah pembawa air tanah (akuifer) terbagi lagi menjadi beberapa lapisan yang semakin kompleks dan sifatnya sangat lokal 27).

Akuifer Jakarta secara geologis memperlihatkan strata tanah yang sangat beragam dan sangat kompleks. Untuk membagi secara tegas lapis demi lapis pada akuifer Jakarta, hampir tidak mungkin. Disana sini terdapat zona-zona air tanah yang terperangkap dalam lensa-lensa kecil. Walaupun agak sulit untuk dikelompokkan secara vertikal, secara kasar akuifer Jakarta dapat dikelompokkan menjadi 3 (tiga) lapis, yakni lapis kesatu merupakan akuifer air tanah dangkal (akuifer bebas) yang mempunyai kedalaman hingga 50 meter dibawah muka tanah, lapis kedua merupakan akuifer tertekan (akuifer artesis) mempunyai kedalaman antara 50 hingga 150 meter dibawah muka tanah dan lapis ketiga merupakan akuifer tertekan, mempunyai kedalaman antara 150 hingga 250 meter dibawah permukaan tanah. Akuifer artesis lazim juga disebut akuifer dalam. Dilihat dari segi jenis tanahnya, akuifer Jakarta pada umumnya merupakan butiran pasir lepas, tanah aluivial walaupun diselang seling dengan tanah lempung yang kedap air (yang ini kelak membuat akuifer itu tidak menerus) mempunyai potensi yang sangat baik sebagai penyimpan air tanah ${ }^{12)}$.

Jika dilihat secara lokal, dengan tingkat kelulusan yang tinggi, maka dapat diperkirakan bahwa porositas dan konduktivitas hidrolis mempunyai besaran yang tinggi, akan tetapi mengingat kompleksitas basin yang sedemikian tinggi, dimana akuifer sering dijumpai tidak menerus, mengakibatkan kecepatan aliran air tanah secara menyeluruh (total) yang rendah. Dampak dari rendahnya kecepatan aliran air tanah ini dapat menyebabkan defisit neraca air pada wilayah atau kawasan tertentu, terutama yang jauh dari daerah imbuhan ${ }^{25)}$.

Tingkat produktivitas akuifer Jakarta dapat dibagi menjadi 3 (tiga) tingkatan, yakni :

1. Akuifer dengan produksi baik, menghasilkan air tanah diatas 5 liter/detik.

2. Akuifer dengan produksi sedang, menghasilkan air tanah 5 liter/detik.

3. Akuifer dengan produksi rendah, menghasilkan air tanah dibawah 5 liter/detik.

Akuifer dengan produksi baik berada tepat di bawah wilayah DKI.

$\mathrm{Di}$ sebelah barat, disekitar wilayah Tangerang akuifer mempunyai produksi baik dan sedang. Dikawasan ini juga terdapat batuan kedap air yang juga menjadi batas fisik akuifer Jakarta untuk sebelah barat, sedangkan disebelah timur, dikawasan Bekasi, akuifer mempunyai produktivitas yang sangat rendah, sehingga hampir tidak mungkin digunakan sebagai sumber air yang dapat diandalkan. Sejumlah batuan juga berada dikawasan ini sehingga ini merupakan batas timur dari akuifer Jakarta

Dari uraian diatas dapat disimpulkan bahwa akuifer Jakarta mempunyai batas fisik yang meliputi 3 (tiga) wilayah propinsi (Banten, Jawa Barat dan DKI) dan lebih rinci lagi terdiri atas 12 (dua belas) pemerintah daerah tingkat II yakni Kabupaten Bogor, Kota Bogor, Kota Depok, Kabupaten Tangerang, Kota Tangerang, Kota Jakarta Selatan, Jakarta Barat, Jakarta Pusat, Jakarta Timur dan Jakarta Utara ${ }^{25)}$.

\section{Penggunaan Air Tanah Dan Permasalahannya}

Pengguna air tanah basin Jakarta meliputi penduduk yang bermukim di wilayah JABODETABEK, jika dilihat secara ringkas, kondisi sekarang dan kemudian penulis mencoba untuk memproyeksikannya hingga tahun 2025, perkiraan jumlah populasi, kebutuhan air bersih dan kebutuhan air tanah akan meningkat seperti disajikan pada tabel 1 dibawah ini dengan asumsi bahwa :

- Kebutuhan air bersih ini ditentukan dengan perkiraan konsumsi air bersih perorang perhari sebesar 200 liter, sudah termasuk kebutuhan untuk industri, dll.

- Perhitungan proyeksi jumlah penduduk, proyeksi kebutuhan air bersih dan proyeksi kemampuan PDAM memproduksi air bersihnya dilakukan dengan menggunakan analisa regresi dengan kecenderungan disesuaikan dengan perkembangan yang sedang berlangsung (eksponensial, logaritmik, polynomial atau linier)

Tabel 1. Kondisi jumlah penduduk, kebutuhan air bersih dan kemampuan PDAM memproduksi air bersih dan kebutuhan air tanah

\begin{tabular}{|l|l|l|l|}
\hline Jenis Obyek & Satuan & \multicolumn{1}{|c|}{$\begin{array}{c}\text { Kondisi } \\
\mathbf{2 0 0 2}\end{array}$} & $\begin{array}{c}\text { Proyeksi } \\
\mathbf{2 0 2 5}\end{array}$ \\
\hline $\begin{array}{l}\text { 1. Jumlah } \\
\text { Penduduk }\end{array}$ & jiwa & 21.600 .698 & 27.800 .000 \\
\hline $\begin{array}{l}\text { 2. Kebutuhan } \\
\text { air bersih }\end{array}$ & Juta $\mathrm{m}^{3}$ & 1548 & 2.000 \\
\hline $\begin{array}{l}\text { 3. Produksi } \\
\text { PDAM }\end{array}$ & Juta $\mathrm{m}^{3}$ & 561.21 & 645 \\
\hline $\begin{array}{l}\text { 4. Kebutuhan } \\
\text { air tanah }\end{array}$ & Juta $\mathrm{m}^{3}$ & 986,79 & 1.355 \\
\hline
\end{tabular}

Sumber : Hasil perhitungan

Data kondisi eksisting kontur tinggi muka air tanah dan tinggi tekan air tanah menunjukkan bahwa kondisi akuifer basin Jakarta tidak menunjukkan gambaran yang memuaskan. Muka air tanah menunjukkan penurunan terjadi sejalan 
dengan berjalannya tahun. Bahkan dibeberapa kawasan besaran penurunan tinggi tekan air tanah yang ekstrim. Dikawasan Jakarta Barat lokasi sekitar Mookervart (TOL Bandara) penurunan tinggi tekan hingga negative (-) 20 meter pada tahun 1986 menjadi hingga (-) 40 meter pada tahun 2000, demikian juga dengan tinggi tekan air tanah disekitar Pulomas terjadi penurunan hingga (-) 20 meter terhadap muka air laut pada tahun 1986 menjadi (-) 25 meter pada tahun 2000.

Pada tahun 2000 pula data pengamatan menunjukkan penurunan tinggi tekan (-) 30 meter dikawasan Bekasi Utara. (Gambar 2 dan 3) 17,32). Pemerintah Daerah DKI Jaya mengeluarkan peraturan yang diperkirakan dapat memberikan dampak yang signifikan dalam pengembalian kondisi muka air tanah melalui SK Gubernur no. 115 tahun 2001, akan tetapi masih belum memberikan hasil yang memuaskan.

Berdasarkan uraian diatas, dapat diidentifikasikan masalah masalah sebagai berikut :

1. Meskipun akuifer basin Jakarta mempunyai karakteristik yang baik sebagai penyimpan air tanah, harus dikaji apakah secara kuantitatif neraca air tanah sudah menunjukkan besaran yang seimbang antara ekstraksi (pengambilan) dan imbuhannya.

2. Secara hidrolis karaktetristik akuifer menentukan kecepatan aliran air tanah, sehingga dari aspek ini dapat diperkirakan apakah kecepatan air tanah dapat mengimbangi kecepatan pengambilan (ekstraksi) air tanah oleh penduduk. Dengan melihat kenyataan dilapangan, terlihat bahwa beberapa kasus kekurangan air tanah hingga menurunnya muka air tanah yang sangat dalam, dapat dipastikan bahwa hal ini merupakan cerminan ketidak seimbangan antara tingkat pengambilan air tanah dan kecepatan air tanah. Terlebih lagi kasus penurunan tinggi tekan air tanah dalam yang paling parah terjadi di kawasan utara Jakarta yang notabene jauh dari daerah imbuhan, sehingga dapat disimpulkan bahwa faktor jarak relatif antara lokasi ekstraksi dan daerah imbuhan dan juga rendahnya kecepatan aliran air tanah merupakan masalah yang memicu terjadinya penurunan muka air tanah dan hal ini belum terpecahkan.

3. Tindakan penanggulangan kekurangan air tanah tidak pernah berhasil mengatasi masalah pokok, dan kebijakan pengelolaan sumberdaya air tanah yang diterapkan dapat dikatakan tidak pernah efektif mengatasi masalah, hal ini terbukti bahwa setiap tahun masalahnya berulang bahkan mungkin lebih parah. Warga tetap kekurangan air bersih, dan air tanah tidak mengganti sumber air bersih alternatif.

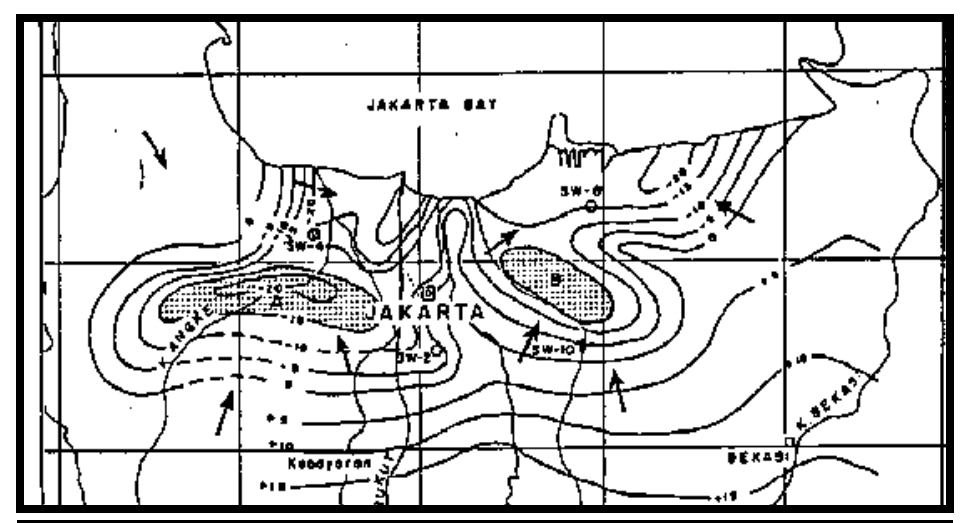

(a)

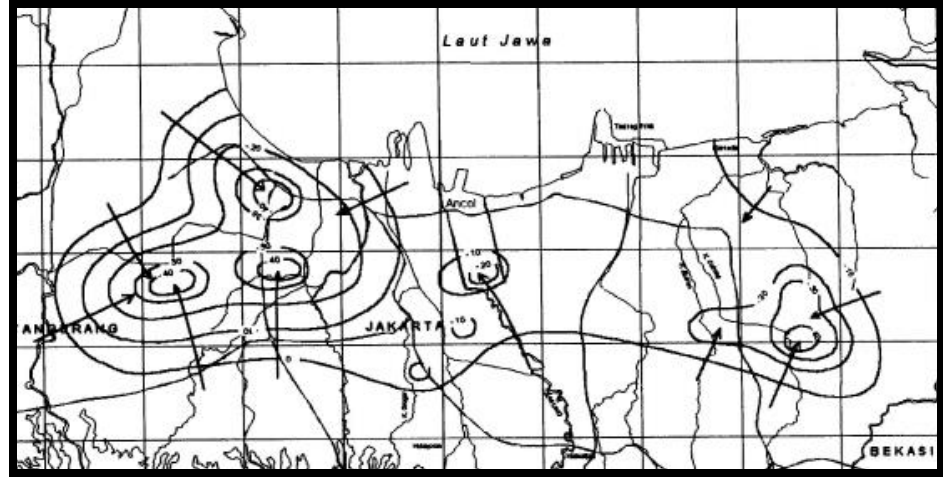

(b)

Gambar 2. Kontur piezometrik air tanah dalam, lapis 1 (kedalaman dibawah - $140 \mathrm{~m}$ )

(a). Kondisi tahun 1987 (Indec, 1987), (b). Kondisi tahun 2000 (Wandowo, 2000) 


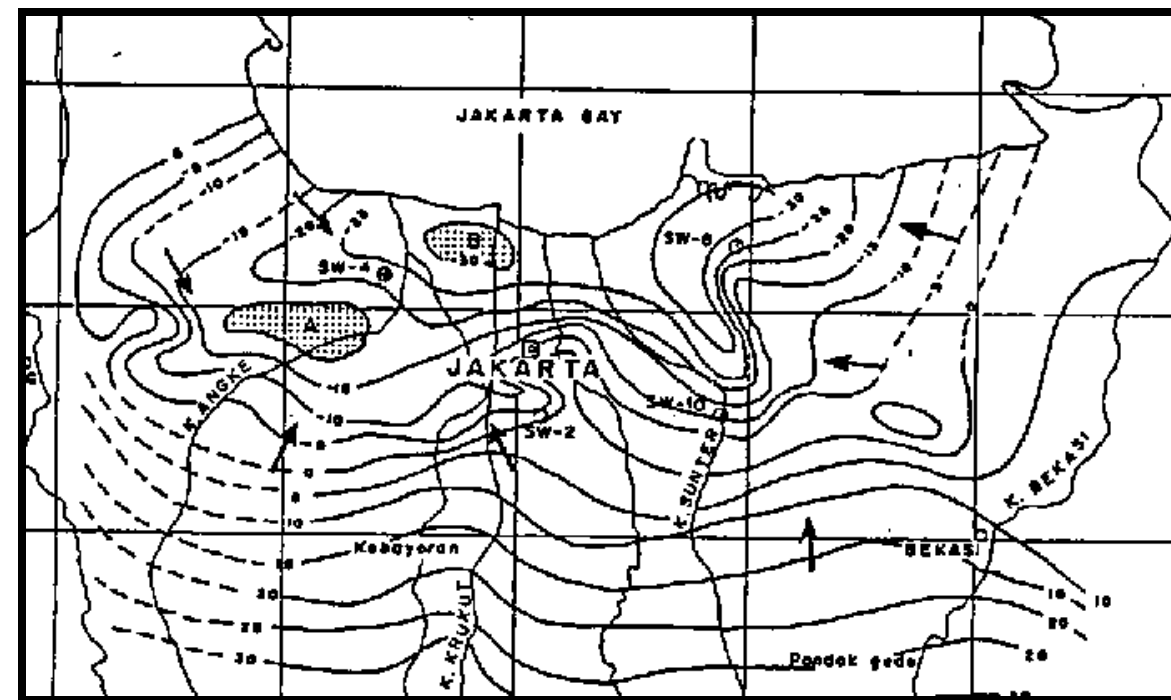

(a)

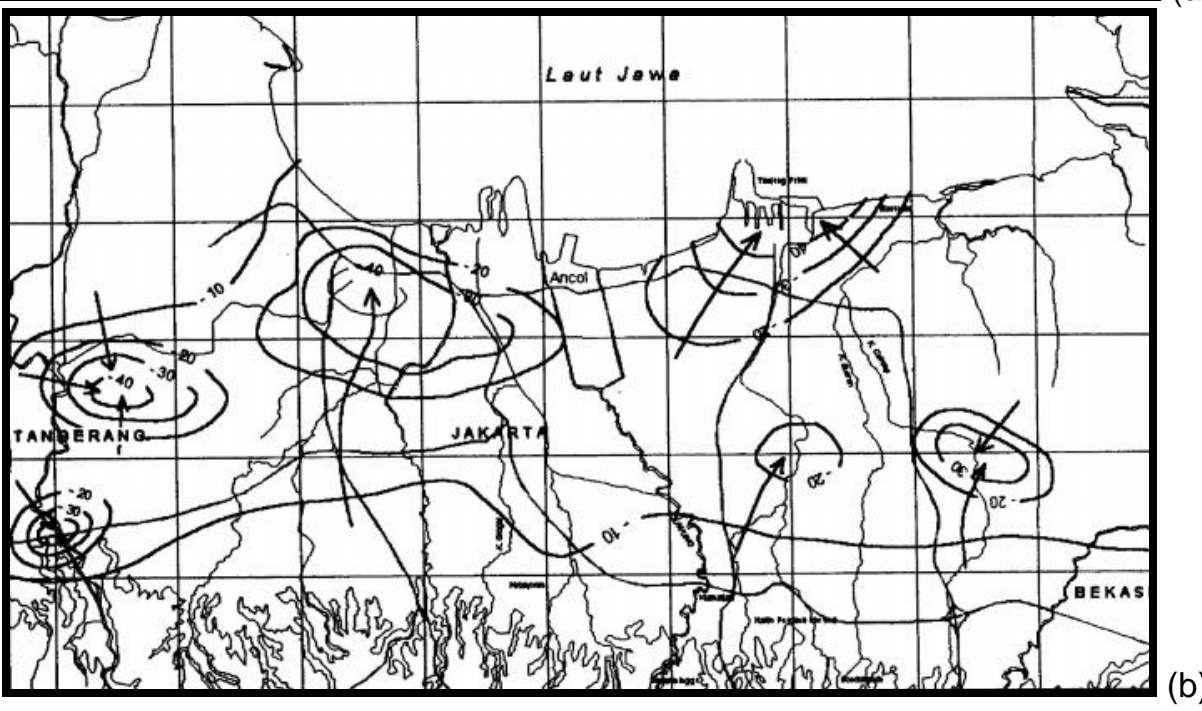

Gambar 3. Kontur piezometrik air tanah dalam, lapis 2 (kedalaman $40-140 \mathrm{~m}$ ). (a). Kondisi tahun 1987 (Indec, 1987), (b). Kondisi tahun 2000 (Wandowo, 2000)

Di samping masalah seperti yang telah disebutkan diatas, ada beberapa pertanyaan yang dijadikan arahan untuk mendapatkan solusi yang paling tepat atau optimal, yaitu :

Berapakah tingkat kebutuhan air bersih warga JABODETABEK? Berapa besar kemampuan PDAM memasok air dan berapa tingkat kebutuhan air tanah? Berapa besar potensi air tanah akuifer Jakarta?

1. Sampai sejauh mana efektifitas koordinasi kelembagaan pengendali sumberdaya air tanah menjalankan peraturan pengendalian sumberdaya air tanah sehingga dapat dijalankan secara konsekuen?

2. Dapatkah imbuhan buatan sebagai pengganti imbuhan alami, meningkatkan potensi air tanah?

\section{Konsep Pemecahan Masalah Air Tanah Jakarta}

\subsection{Kependudukan Dan Penggunaan Air Tanah}

Perkiraan proyeksi penduduk, kebutuhan air bersih dan kebutuhan air tanah untuk kawasan JABODETABEK, disajikan seperti pada Gambar 4 dan Gambar 5 dibawah ini. Dari grafik yang disajikan pada gambar 4 dan 5 diatas, diketahui bahwa kebutuhan sumberdaya air tanah ini akan meningkat sejalan dengan pertambahan jumlah penduduk. Hal ini berarti jika diasumsikan tidak terjadi perubahan pola pengelolaan dan pemanfaatan air tanah, maka sudah dapat dipastikan bahwa kondisi air tanah akan bertambah parah, sehingga penggunaan air tanah sudah tidak berkelanjutan lagi.

Kebutuhan air bersih warga JABODETABEK yang pada saat ini diperkirakan sebesar \pm 1549 juta $\mathrm{m} 3$ dan jumlah ini masih terus meningkat di masa masa yang akan datang. Dengan kemampuan PDAM yang 
terbatas, sebagian besar dari kebutuhan air ini didapat dari air tanah. Pada tahun 2002 ini PDAM hanya dapat menyediakan air bersih sebesar 339 juta m3 dan belum ada penambahan kapasitas hingga sekarang, jadi secara garis besar sisanya sebesar \pm 1210 juta m3 dipenuhi dari air tanah. Untuk DKI Jakarta, dari perhitungan kebutuhan air bersih \pm 612 juta m3/tahun, PDAM Jakarta hanya mampu menyediakan 232 juta $\mathrm{m} 3 /$ tahun atau $\pm 38 \%$ dari kebutuhan, sehingga sisanya sebesar \pm 380 juta m3/tahun mengandalkan potensi air tanah.

Dari sisi neraca air tanah, banyaknya curah hujan yang jatuh di basin Jakarta hingga mencapai antara 2000 - 3500 mm pertahun, jika luas basin \pm 3000 km3, maka basin Jakarta menerima air hujan antara 6000 - 10.500 juta m3 pertahun. Dari presipitasi yang jatuh di basin Jakarta ini, diperkirakan 1230 hingga 4850 juta m3 setiap tahun akan meresap kedalam tanah. Jika $5 \%$ dari air yang meresap ini terserap lebih dalam oleh akuifer artesis, maka potensi air tanah dangkal berkisar antara 1170 hingga 4600 juta m3 pertahun sementara air tanah dalam mempunyai potensi sebesar 62 hingga 230 juta m3.

Di sisi lain, pembangunan kota Jakarta dan wilayah sekitarnya (BODETABEK) sudah sedemikian rupa sehingga terdapat banyak sekali bangunan, jalan raya dan areal parkir yang menutupi permukaan tanah. Luas tanah terbuka menjadi semakin sempit. Kegiatan penutupan permukaan tanah ini masih berlangsung, sehingga potensi pengisian kembali (imbuhan alam) air tanah yang diharapkan dari peresapan langsung semakin menurun.

Seperti yang diketahui, bahwa tanah terbuka ini seharusnya dapat menjadi tempat peresapan air hujan yang turun ke bumi yang selanjutnya menjadi tempat pengisian langsung bagi air tanah, terutama untuk air tanah dangkal, akan tetapi harapan ini tidak menjadi kenyataan. Akibat semakin menyempitnya lahan untuk peresapan air hujan, kapasitas air tanah yang dapat dimanfaatkan jumlahnya menurun. Tidak terjadi keseimbangan antara pengisian air tanah dan pengambilannya.

Dari perkiraan neraca air tanah diatas, diketahui bahwa persediaan air tanah maupun air permukaan seharusnya cukup untuk memenuhi kebutuhan air bersih penduduk JABODETABEK. Akan tetapi di beberapa kawasan, terutama di kawasan utara Jakarta terjadi masalah air tanah, dan yang sering mengemuka adalah masalah kualitas dan kuantitas air tanah.

Akan tetapi sebelum itu terjadi, ada beberapa tindakan pengatasan masalah yang dapat dilakukan yakni tindakan fisik menambah cadangan air tanah, yakni merupakan tindakan pintas memasukkan air kedalam akuifer. Proses ini seharusnya dilakukan dengan memanfaatkan kinerja akuifer dalam mengembalikan keseimbangan hidrolisnya, akan tetapi tidak dapat tercapai karena kecepatan pengambilan tidak dapat diimbangi oleh kecepatan aliran air tanah untuk mencapai keseimbangan hidrolisnya, sehingga dibeberapa kawasan mengalami penurunan yang sangat hebat, terutama di area yang jauh dari daerah pengisian.

Untuk mengembalikan tinggi muka air tanah dangkal, program sumur resapan. yang dituangkan kedalam SK Gubernur 115 tahun 2000 tentang sumur resapan perlu ditingkatkan efektifitas penerapannya. Sementara itu untuk akuifer tertekan perlu diadakan imbuhan buatan. Karena skema imbuhan buatan ini dianggap lebih efektip dibanding dengan metode yang lain (Hutasoit, 2003). Pengisian air tanah ini dilakukan pada lokasi - lokasi yang mengalami krisis yang paling parah, yakni lokasi dimana terjadi depresi kerucut yang sangat dalam. Teknologi skema penyuntikan air kedalam akuifer ini sudah dikenal dan diterapkan di Amerika Serikat (Orange County, California). Maksud dari penyuntikan air kedalam akuifer ini juga untuk meninggikan muka air tanah ${ }^{18)}$.

Selain daripada penanggulangan secara fisik, tindakan koordinasi pengelolaan sumberdaya air tanah secara terpadu juga harus dilakukan secara bersamaan. Pihak terkait (stakeholders) terdiri atas para pemegang kendali di Pemerintah Daerah yang warganya merupakan pengguna air tanah basin Jakarta ini. Koordinasi pengelolaan ini merupakan lintas sektoral yang merupakan kerjasama antar 3 propinsi (Jawa Barat, Banten dan DKI). Kebijakan pengelolaan air tanah yang selama ini hanya berlaku lokal sudah seharusnya berlaku secara lebih luas. Masing masing stakeholder mempunyai suatu kepentingan yang sama (something in common) dalam mengatasi masalah air tanah ini.

Pelaksanaan peninggian muka air tanah dilakukan dengan cara menyuntikkan air kedalam akuifer, Sebelum pelaksanaan penyuntikan itu dilakukan, karena membutuhkan biaya yang mahal dan waktu yang relative lama, maka terlebih dahulu dilakukan simulasi model yang bertujuan untuk mengamati perilaku air tanah jika dilakukan skema penyuntikan (imbuhan buatan). Dari model ini pula akan diketahui secara kuantitatif volume air baku yang akan disuntikkan dan lokasi tempat penyuntikan. Simulasi permodelan menggunakan Visual Modflow (Waterloo Hydrologic, 1996). Skema penyuntikan akan dilakukan terhadap akuifer tertekan. Hasil simulasi disajikan seperti pada gambar $6 \sim 9$. 


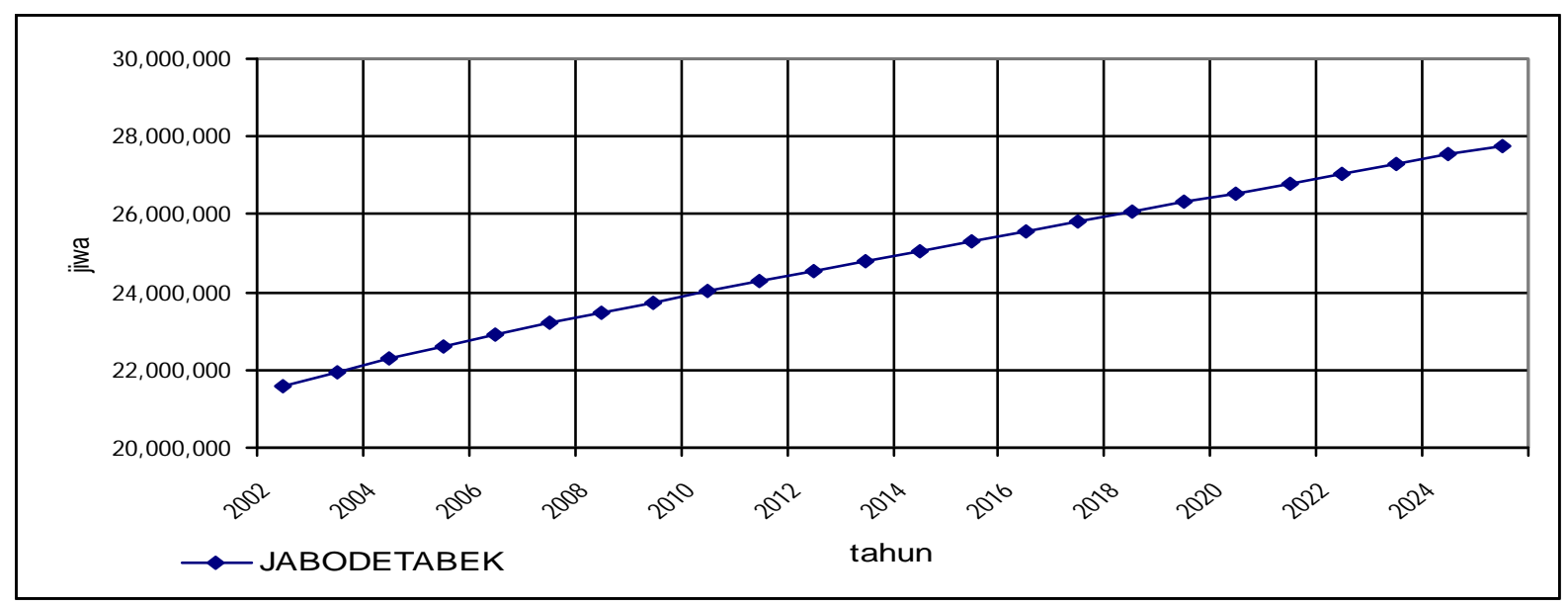

Sumber: Hasil perhitungan

Gambar 4. Proyeksi jumlah penduduk JABODETABEK hingga tahun 2025

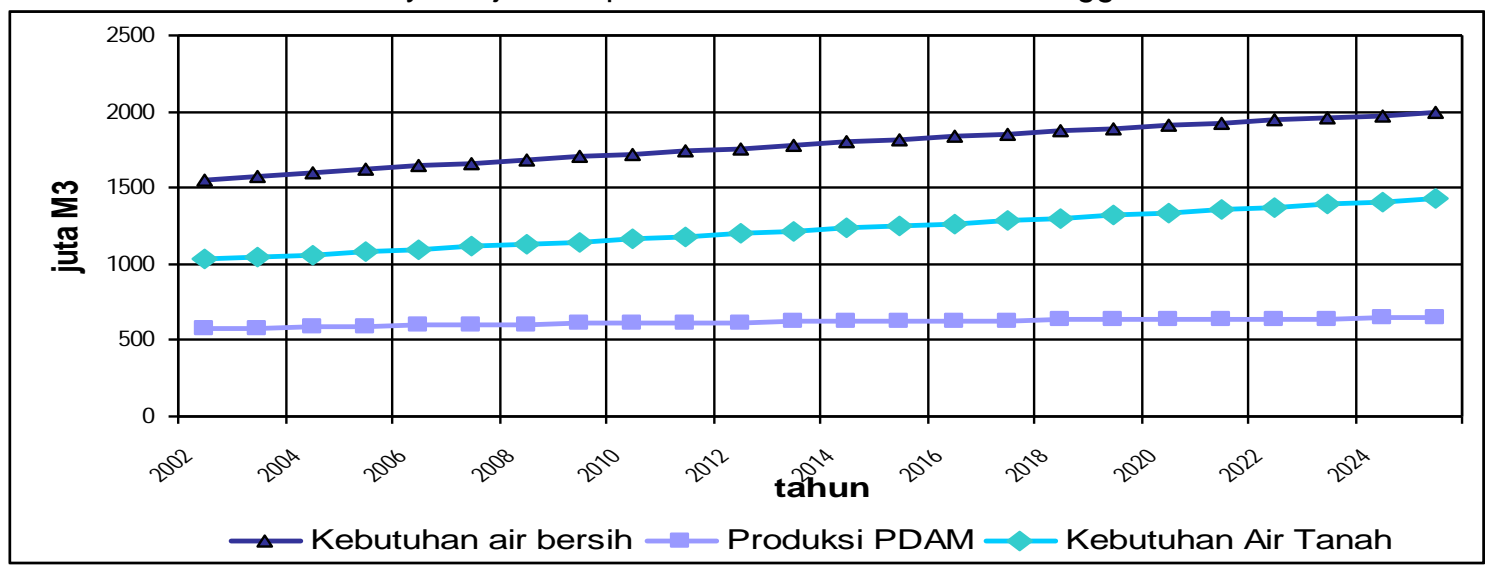

Sumber: Hasil perhitungan

Gambar 5. Proyeksi kebutuhan air bersih, produksi PDAM dan kebutuhan air tanah untuk wilayah JABODETABEK hingga tahun 2025

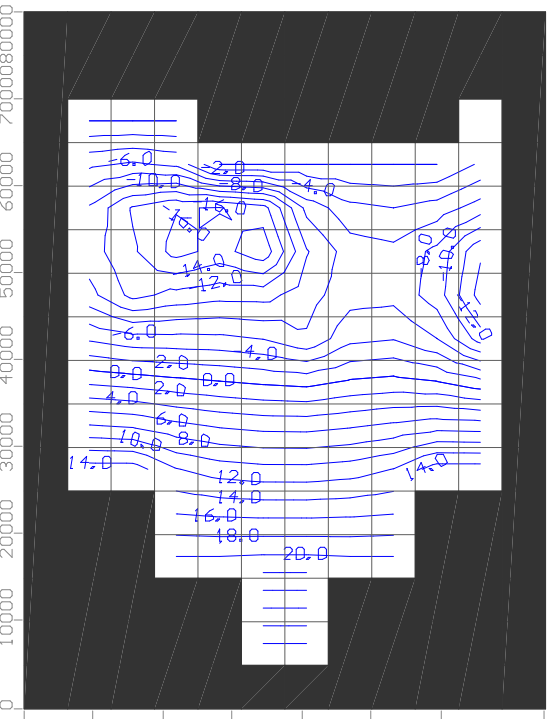

Gambar 6. Hasil simulasi imbuhan buatan untuk akuifer lapis I (kedalaman dibawah -140 m)

(Situasi sebelum imbuhan dilakukan)

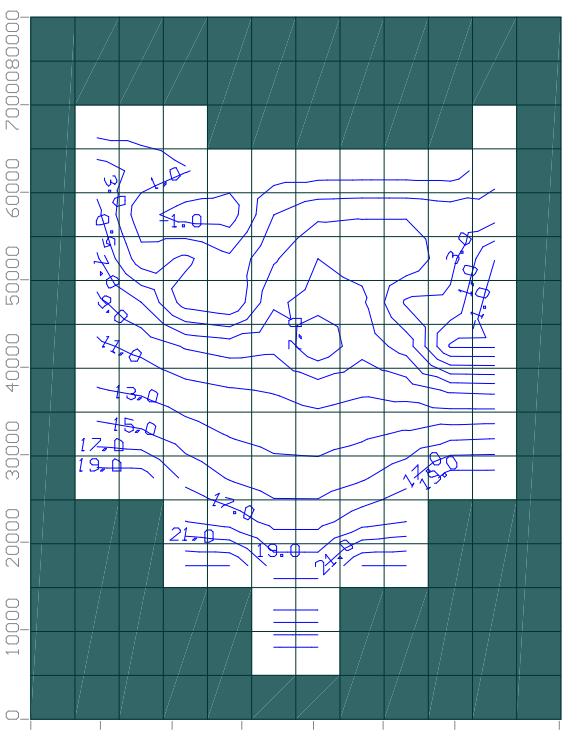

Gambar 7. Hasil simulasi imbuhan buatan untuk akuifer lapis I (kedalaman dibawah -140 m (Situasi sesudah imbuhan dilakukan) 


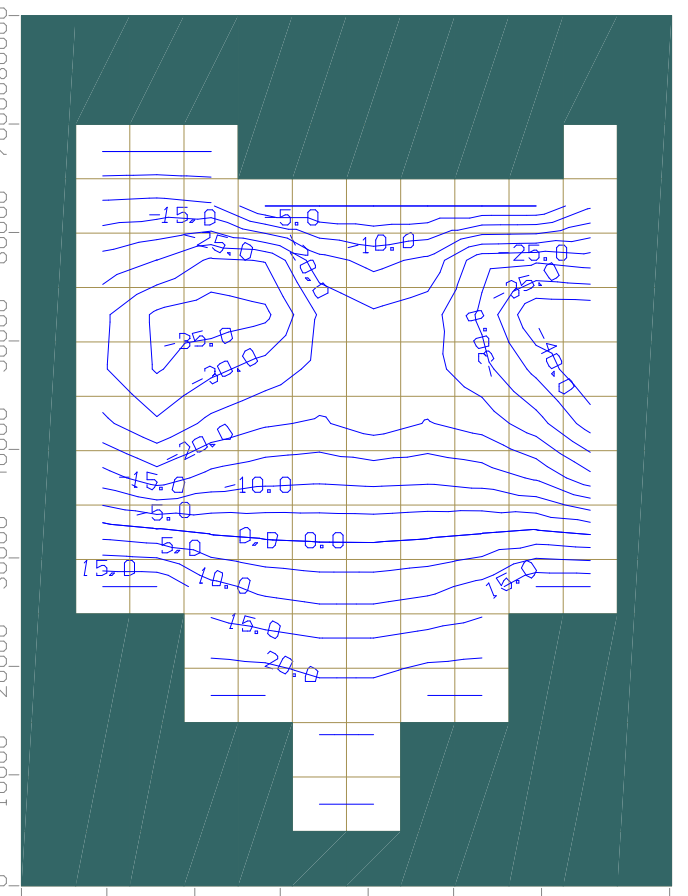

Gambar 8. Hasil simulasi imbuhan buatan untuk akuifer lapis 2 (kedalaman -40 hingga -140 m)

(Situasi sesudah imbuhan dilakukan)

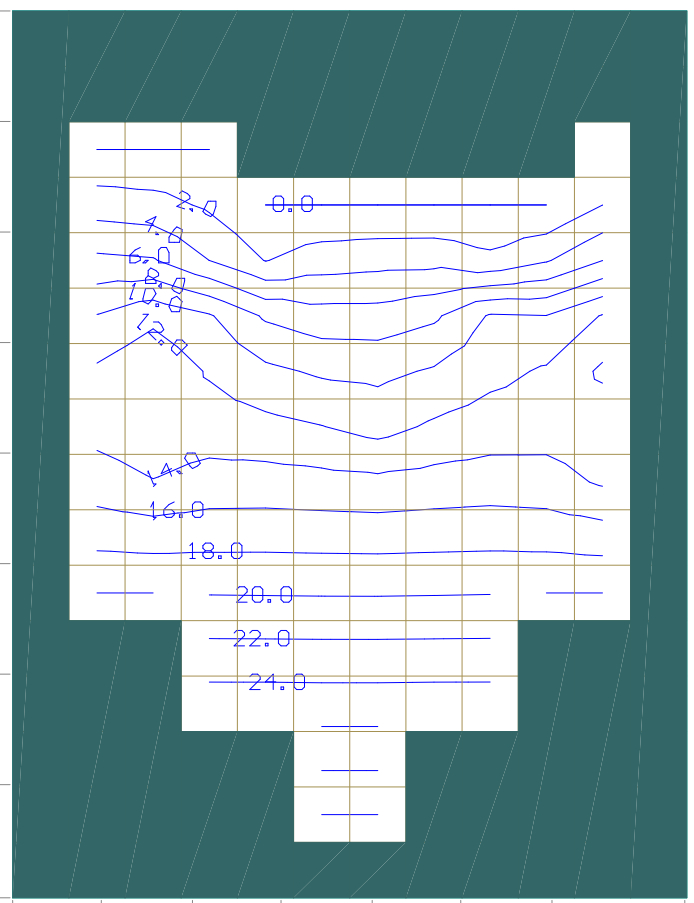

Gambar 9. Hasil simulasi imbuhan buatan untuk akuifer lapis 2 (Situasi sebelum imbuhan dilakukan)

Adapun dari simulasi permodelan penyuntikan air tanah, hasilnya diperlihatkan seperti pada gambar di bawah ini.

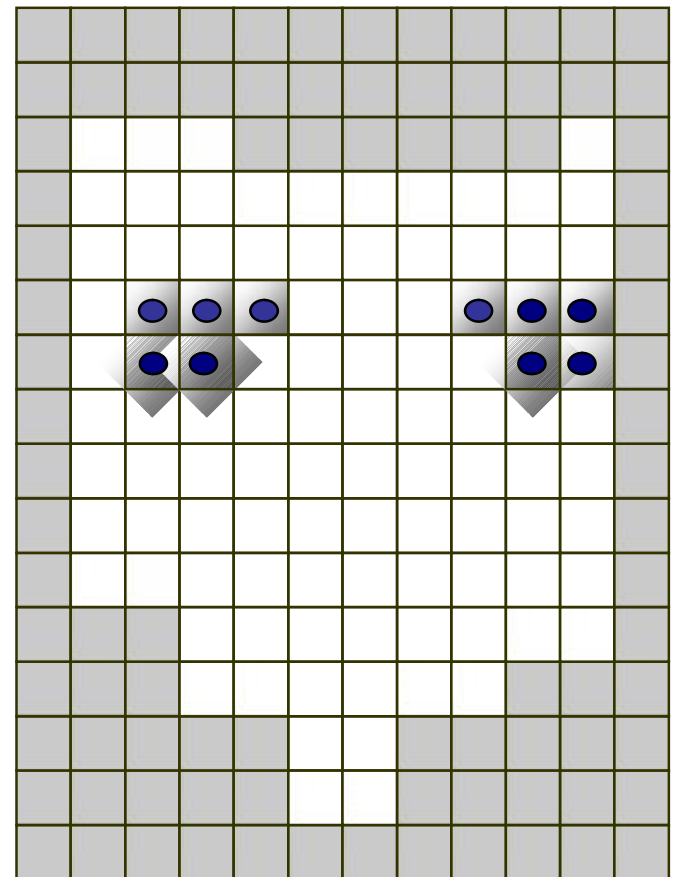

Gambar 10. Lokasi imbuhan buatan pada akuifer air tanah dangkal (Lapis 2)

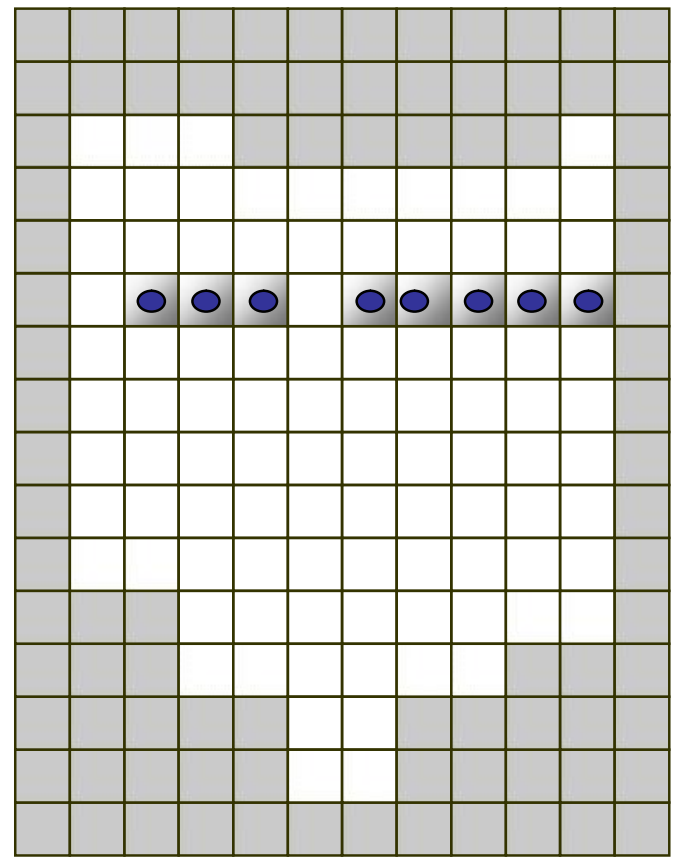

Gambar 11. Lokasi imbuhan buatan pada akuifer air tanah dangkal (Lapis 1)

Pada akuifer tertekan lapis kedua, terdapat 10 sel yang direkomendasikan untuk pelaksanaan penyuntikan. Sumur penyuntikan yang direkomendasikan konsentrasikan disekitar TOL Bandara untuk Jakarta Barat dan di Jakarta timur disekitar Pulogadung. Jumlah sumur penyuntikan yang direkomendasikan sebanyak 10 unit sumur dengan besaran air total yang akan disuntikkan adalah $130.000 \mathrm{~m}^{3}$ perhari atau 
kira kira 1500 liter/detik. Dengan air sebanyak itu, setiap sumur akan dialirkan air sebanyak kira kira 150 liter/detik untuk disuntikkan kedalam akuifer tertekan lapis kedua. Pada akuifer air tanah tertekan lapis terbawah (lapis kesatu) dengan kedalaman di bawah 140 m direkomendasikan 8 unit sumur yang akan digunakan sebagai imbuhan buatan. Adapun lokasi sumur tersebar disepanjang kawasan Jakarta pusat memanjang dari mulai area tol bandara hingga Jakarta Timur disekitar Pulomas seperti diperlihatkan pada gambar 8. Volume total air yang disuntikkan kedalam akuifer sebesar $100.000 \mathrm{~m}^{3}$ untuk setiap hari atau kira-kira 1.160 liter/detik. Dengan demikian setiap sumur akan dialirkan air sebanyak 145 liter/detik.

\subsection{Strategi Pengelolaan Sumberdaya Air Tanah basin Jakarta}

Seperti diketahui bahwa sarana penyediaan air bersih untuk Jakarta tidak sepenuhnya dapat diperoleh dari Perusahaan Air Minum, maka air tanah merupakan salah satu cara yang paling banyak dipilih bagi warga Jakarta untuk mendapatkan air bersih sebagai sumber air bersih alternatif. Air baku yang dipergunakan untuk penyediaan air bersih yang dilayani oleh PDAM berasal dari air permukaan. Akan tetapi jangkauan pelayanan PDAM hanya mampu melayani bagian kota tertentu saja, sehingga masyarakat Jakarta harus mengandalkan air tanah sebagai pemenuhan kebutuhan air bersihnya. Seperti juga diketahui bahwa sangat sedikit atau bahkan tidak satu kota metropolitanpun didunia ini yang mengandalkan penyediaan air bersihnya utamanya dari air tanah, kecuali Jakarta.

Keterbatasan penyediaan air permukaan ini juga memicu industri dalam usaha pemenuhan air bersihnya. Beberapa industri menggunakan air tanah tidak cukup hanya dari sumur dangkal saja, akan tetapi sudah merambah air tanah yang lebih dalam, karena pertimbangan kapasitas yang lebih besar. Akibat pemanfaatan air tanah yang semakin tidak terkendali menyebabkan penurunan muka air tanah (pada air tanah dangkal) juga penurunan tinggi tekan (pada air tanah tertekan). Sebagai akibat dari penurunan muka air tanah dan penurunan tinggi tekan yang ekstrim ini akan menurunkan pula muka air tanah (dan tinggi tekan) disekitar industri tersebut, yang selanjutnya akan dapat memicu ketegangan sosial, karena secara langsung berdampak pada penyediaan air bersih warga sekitarnya.

Dari segi fisik, secara geologis akuifer Jakarta mempunyai kemampuan yang baik dalam menyimpan air tanah. Akan tetapi ini sifatnya hanya lokal, untuk secara keseluruhan, kemampuan untuk mengalirkan air tanah hingga ke kawasan utara Jakarta sangat rendah. Kecepatan aliran air tanah yang diekspresikan dengan angka kelaluan hidrolis yang rendah, yakni berkisar 0,00002 $\mathrm{m} /$ detik hingga 0,0001 $\mathrm{m} /$ detik, atau $\pm 2 \mathrm{~m} /$ hari. Dengan kata lain bahwa kecepatan pengaliran air tanah hanya sekitar 2 $\mathrm{m} /$ hari ${ }^{33)}$. Oleh karena itu banyak terjadi masalah. Masalah yang menonjol adalah turunnya muka air tanah. Semakin keutara masalah penurunan muka air tanah semakin parah, hingga terjadi depresi kerucut yang sangat dalam.

Konsep pemecahan masalah air tanah yang utama adalah ditujukan untuk menaikkan muka air tanah (dan tinggi tekan). Wacana pengisian buatan akan lebih tepat jika diterapkan untuk mengisi air tanah tertekan, sedangkan untuk air tanah dangkal karena masih dapat mengandalkan resapan dari permukaan tanah. Pengelolaan air tanah dangkal akan lebih tepat jika diterapkan suatu kebijakan yang melibatkan stakeholders yang lebih luas sesuai dengan batasan fisik akuifer basin Jakarta.

Sebagai salah satu usaha agar pemanfaatan air tanah dapat lebih berkelanjutan, kebijakan pengisian air tanah dangkal, melalui Keputusan Gubernur nomor 115 tahun 2001 tentang pembuatan sumur resapan di Propinsi DKI Jaya dirasakan kurang efektip dalam mengatasi permasalahan air tanah. Oleh karena itu peraturan perundangan ini sudah selayaknya diadakan penyempurnaan, yakni disempurnakan sedemikian rupa sehingga peran masyarakat luas ikut dilibatkan dalam mengatasi masalah air tanah.

Sebagai arahan dalam perumusan kebijakan yang akan ditempuh dibidang sumberdaya air tanah, ditujukan agar ${ }^{21)}$ :

a. Mengelola sumberdaya air tanah dari hulu hingga hilir dengan mengacu pada DAS 14 sungai yang mengalir dikawasan JABODETABEK.

b. Memberdayakan masyarakat bagi peningkatan kesejahteraan masyarakat.

c. Memelihara kawasan konservasi yang sudah ada dan menetapkan konservasi baru diwilayah tertentu.

d. Mengikutsertakan masyarakat dalam rangka menanggulangi permasalahan air tanah.

Dengan arahan kebijakan ini, strategi yang ditempuh dalam bidang sumberdaya air tanah adalah :

a. Mengoptimalkan upaya konservasi rehabilitasi dan penghematan sumberdaya air (baik air permukaan maupun air tanah) melalui sosialisasi penghematan, meningkatkan kerja sama antar unit dan instansi terkait dalam pengelolaan dan penegakan hukum. 
b. Meningkatkan partisipasi dan akuntabilitas masyarakat, swasta dan pemerintah dalam mengatasi masalah air tanah (baik kualitatif maupun kuantitatif), mengikutsertakan masyarakat dalam penegakan hukum dalam penanganan sumber sumber penyebab permasalahan.

\subsection{Konsep Pengelolaan Sumberdaya Air Lintas Wilayah}

Secara geografis akuifer Jakarta mempunyai area permukaan yang tersebar meliputi 3 wilayah propinsi, yakni :

1. Propinsi DKI Jakarta,

2. Propinsi Jawa Barat yang terdiri atas wilayah (Kota dan kabupaten Bogor, Kota Depok, Kota dan Kabupaten Bekasi)

3. Propinsi Banten yang terdiri atas wilayah (Kota dan Kabupaten Tangerang)

Selain itu diatas wilayah geografis Propinsi DKI Jakarta mengalir 14 buah sungai, wilayah Propinsi lain juga dialiri oleh beberapa dari sungai sungai tersebut.

Berkaitan dengan kondisi ini maka beberapa wilayah tersebut mempunyai suatu kesamaan kepentingan (something in common), yakni :

1. Karena keempatbelas sungai tersebut mengalir, maka ada suatu kondisi yang tidak dapat dihindari bahwa warga dari gabungan wilayah (JABODETABEK) mempergunakan sungai sungai tersebut (terlepas dari fungsi apapun)

2. Warga di wilayah ini juga mempergunakan akuifer air tanah yang sama dalam memanfaatkan air tanahnya.

Dengan adanya persamaan kepentingan ini, maka terdapat alasan yang kuat bahwa perlu diusulkan suatu sistem pengelolaan DAS bersama dengan tema "one river one management".

Beberapa aspek yang perlu mendapat perhatian dalam membentuk badan pengelola adalah :

1. Regulasi yang mengatur standar kualitas keempatbelas sungai

2. Regulasi yang mengatur perlindungan hulu seluruh sungai sungai diatas.

3. Regulasi yang mengatur daerah tangkapan air

4. Regulasi yang mengatur pemanfaatan air tanah akuifer Jakarta

5. Regulasi yang mengatur penggunaan lahan

6. Pemantauan bersama kualitas dan kuantitas sungai dan potensi air tanah

7. Regulasi yang mengatur sistem dan pola imbuhan air pada akuifer air tanah Jakarta.

Adapun tanggung jawab badan pengelola harus diatas gubernur atau setingkat menteri (MENDAGRI) karena badan pengelola ini mempunyai daerah kewenangan yang melintasi batas propinsi.

\section{Pembahasan Hasil Kajian}

Sistem air tanah di kawasan Jakarta dan sekitarnya, yang merupakan daerah studi ini, tidak lepas dari sistem sumberdaya air secara keseluruhan. Dampak yang sedang dialami oleh badan air tanah tidak hanya disebabkan oleh pola pemakaian atau pemanfaatan air tanah yang kurang terorganisasi dengan baik, akan tetapi juga terdapat korelasi pengaruh sebagai akibat pengendalian sumberdaya air keseluruhan secara terpadu. Hal ini dimungkinkan karena adanya siklus hidrologi yang melibatkan seluruh komponen air, baik air angkasa, air permukaan dan air tanah.

Adapun untuk sistem air bawah tanah, sistem akuifer sebenarnya tidak bisa dilihat sebagai sistem hidrogeologi yang rigid dan skematisasi yang kaku sesuai dengan definisi akuifer dan akuitarnya, karena dari interpretasi data pemboran tanah memperlihatkan bahwa ketegasan batas antara akuifer dan akuitard itu sangat berbeda dengan anggapan diatas kertas. Untuk sistem akuifer Jakarta, terdapat lapisan pasir lensa yang ditemui pada kedalaman tertentu, jadi tidak secara tegas mempunyai perbatasan fisik yang jelas, sehingga keterkaitan dengan sistem struktur tanah sekitarnya sangat erat.

Pemaparan fakta dari kondisi sistem air tanah Jakarta seperti yang diuraikan pada uraian sebelumnya yaitu kondisi muka air tanah dari ketiga lapis akuifer maupun kondisi penurunan muka tanah dan juga terdeteksinya air payau, secara umum dapat dikatakan bahwa insiden penurunan muka tanah, penurunan muka air tanah dan terjadinya intrusi air laut, tidak bisa dilihat hanya sebagai akibat pola pemanfaatan air tanah yang buruk saja. Akan tetapi dapat dilihat secara lebih jauh, sistem air tanah merupakan bagian dari sistem hidrogeologi pada khususnya dan sistem hidrologi pada umumnya. Oleh karena itu remedi yang menyeluruh untuk mengatasi permasalahan air tanah ini sebenarnya tidak secara khusus hanya terpusat pola pengambilan saja yang dikendalikan, akan tetapi strategi pengendalian sumberdaya air tanah dan air permukaan secara terpadu juga harus mengemuka.

Penurunan muka air tanah pada beberapa kawasan tertentu terutama pada area dimana terjadi kerucut depresi yang dalam merupakan suatu kenyataan bahwa pada akuifer untuk area ini terjadi ketidakseimbangan terhadap neraca air tanah. Secara umum kapasitas pengambilan air tanah didaerah 
kerucut depresi tersebut melebihi kapasitas pengisiannya. Sehingga terjadi kerucut depresi yang disebutkan diatas. Hal ini dimungkinkan karena terdapatnya kegiatan fisik dikawasan tersebut misalnya kegiatan industri berat yang mengkonsumsi air tanah yang tinggi atau kegiatan lainnya yang juga menggunakan air tanah dalam jumlah besar.

Bila ditinjau lebih jauh terjadinya penurunan muka air tanah yang mencolok ini kemungkinan disebabkan oleh ketidakseimbangan kuantitatif volume air tanah seperti yang telah diuraikan diatas, kemungkinan yang lain adalah property akuifer yang sensitive terhadap ekstraksi air tanah. Properti akuifer ini antara lain adalah porositas tanah, angka kelaluan, koefisien storage, ataupun kondisi kelokalan akuifer itu sendiri, seperti terjadi lensa pengelompokan dan kasus kelokalan yang lain. Bisa juga oleh karena gabungan dari penyebab diatas.

Untuk kasus penurunan muka tanah, dampak yang disebabkan oleh menurunnya muka tanah tidak menjadi satu satunya faktor penyebab. Ada dua penyebab lain yang menyumbang terjadinya penurunan muka tanah, yakni adanya sebagian kegiatan geologi yang menyebabkan terjadinya kompaksi butir tanah yang terjadi sepanjang masa dan adanya beban berat akibat adanya struktur diatas muka tanah, dalam hal ini pada umumnya bangunan bertingkat. Menurut Distamben, DKI (2003), faktor penyebab yang paling dominan adalah beban berat bangunan yang menyumbang $80 \%$ terhadap laju penurunan muka tanah, sedangkan pengambilan air tanah menyumbang $17,5 \%$, yang berarti bahwa proses kompaksi akibat pengambilan air tanah bukan satu satunya penyebab.

Masalah keberadaan air payau didalam akuifer basin Jakarta juga tidak merupakan satu satunya dampak dari pengambilan air tanah yang berlebihan. Disamping gejala bergesernya interface air asin dan air tawar, kehadiran air payau dalam sistem air tanah basin Jakarta juga disebabkan oleh hadirnya air asin sejak ribuan tahun yang silam. Hal ini sudah dibuktikan bahwa keberadaan air asin di beberapa kawasan Jakarta tidak terkait dengan aktifitas pengambilan air tanah (Wandowo, 2000). Juga diketahui bahwa keberadaan air asin yang ditemukan pada beberapa lokasi sumur pemantauan diperkirakan sudah disana sejak jaman purba (Wandowo, 2000)

\section{Kesimpulan dan Saran} bahwa :

Hasil penelitian ini dapat menyimpulkan
1. Dari kajian kependudukan dan kebutuhan air bersih dapat disimpulkan seperti disajikan pada tabel di bawah ini

\begin{tabular}{|c|c|c|c|}
\hline \multirow{2}{*}{$\begin{array}{c}\text { JENIS } \\
\text { ANALISIS }\end{array}$} & \multirow{2}{*}{ SATUAN } & \multicolumn{2}{|c|}{ TAHUN } \\
\hline & & 2002 & 2025 \\
\hline $\begin{array}{l}\text { 1. Jumlah } \\
\text { Penduduk }\end{array}$ & jiwa & 21.600 .698 & 27.779.399 \\
\hline $\begin{array}{l}\text { 2. Kebutuhan } \\
\text { Air bersih }\end{array}$ & Juta $m^{3}$ & $1.548,79$ & $1.994,72$ \\
\hline $\begin{array}{l}\text { 3. Kemampuan } \\
\text { PDAM } \\
\text { memasok air } \\
\text { bersih }\end{array}$ & Juta $\mathrm{m}^{3}$ & 576,86 & 644,91 \\
\hline $\begin{array}{l}\text { 4. Kebutuhan } \\
\text { Air tanah } \\
\end{array}$ & Juta $\mathrm{m}^{3}$ & $1,027.72$ & $1,429.14$ \\
\hline $\begin{array}{l}\text { 5. Ketersediaan } \\
\text { air tanah }\end{array}$ & Juta m³ & $\begin{array}{c}1230- \\
1590\end{array}$ & $?$ \\
\hline
\end{tabular}

Sehingga dari tabel diatas dapat disimpulkan bahwa potensi air tanah akuifer basin Jakarta dalam keadaan kritis, karena perimbangan antara pemakaian dan perkiraan imbuhan alam yang diterima oleh air tanah (akuifer bebas) memperlihatkan perbedaan yang tipis. Ini berarti telah atau sangat dekat dengan saat pertemuan antara laju konsumsi air tanah yang naik dengan ketersediaan sumberdaya yang semakin menurun. Jika tidak dilakukan intervensi maka potensi sumberdaya air tanah akan menurun dan defisit dengan tingkat konsumsi semakin jauh.

2. Kerucut depresi dan penurunan muka tanah (land subsidence) yang terjadi di kawasan utara Jakarta memperlihatkan bahwa distribusi ekstraksi air tanah sangat tidak seimbang. Kondisi yang tidak seimbang ini dimungkinkan karena kecepatan pengisian air tanah pada akuifer bagian utara Jakarta lebih rendah dibandingkan dengan volume ekstraksi total dikawasan terjadinya insiden (kerucut depresi dan land subsidence). Mengingat daerah pengisian air tanah berada dikawasan selatan Jakarta, dan diperlukan waktu yang relatif lama hingga air tanah pengisi sampai di kawasan utara Jakarta, ini juga memperkuat bahwa besaran konduktivitas hidrolis akuifer ini sampai pada tahap terlalu kecil untuk tingkat ekstraksi lokal saat ini.

3. Angka kelaluan yang sangat rendah dan mempunyai rentang variasi yang sangat lebar (terrendah $0.01 \mathrm{~m}$ perhari hingga tertinggi 14 meter perhari) yang memperlihatkan bahwa kecepatan aliran air tanah yang juga rendah, sifatnya lokal (tidak menerus), dengan demikian untuk besaran $k$ (angka kelaluan) dari formasi total akan jauh kebih rendah setelah lapisan pasir itu tidak langsung berhubungan, hal ini 
menyebabkan terjadinya kesenjangan antara laju ekstraksi dengan kecepatan pengisian air dari akuifer sekitarnya. Kecepatan ekstraksi jauh lebih tinggi daripada kecepatan pengisian air tanah, dan sudah terjadi beberapa tahun sehingga berdampak pada insiden penurunan muka air tanah dan penurunan permukaan tanah.

4. Instrumentasi perundang - undangan yang menyangkut pengelolaan sumberdaya air tanah yang diharapkan dapat mengendalikan penggunaan air tanah, tidak berjalan sesuai dengan harapan. Surat Keputusan Gubernur DKI Jakarta Nomor. 115 tahun 2000 hanya efektip untuk pengembang atau pemilik gedung yang sedang dibangun.

5. Skema imbuhan buatan (yang berfungsi menahan laju penurunan muka air tanah dan muka tanah) untuk akuifer air tanah Jakarta trutama pada lokasi insiden yang dimaksud diatas, secara teoritis dapat diterapkan.

6. Dari beberapa fakta dan insiden yang telah terjadi, dapat disimpulkan bahwa pemanfaatan air tanah Jakarta tidak dapat dipertahankan secara jangka panjang. Untuk mengganti pasokan air minum warga, pemanfaatan air permukaan harus lebih diintensifkan.

Saran yang dapat diberikan dalam penelitian ini adalah, sebagai berikut :

1. Diperlukan sistem penyediaan air bersih yang memadai oleh Perusahaan Air Minum DKI Jakarta, yaitu sistem penyediaan air bersih yang tidak bersumber pada air tanah untuk daerah yang mengalami penurunan air tanah yang ekstrim dan untuk daerah pesisir, yaitu dengan :

- Tidak mengembangkan sistem penyediaan air bersih yang berbasis air tanah.

- Memanfaatkan secara optimal sumber air permukaan yang ada di kawasan JABODETABEK.

2. Diperlukan perluasan sistem penyediaan air bersih (yang dalam hal ini dikelola oleh PDAM Jaya) agar lebih menjangkau warga Jakarta secara lebih luas, terutama pada :

- Daerah pesisir, yaitu area dimana air tanahnya mempunyai salinitas tinggi (payau)

- Daerah yang kritis, yaitu daerah yang mengalami penurunan muka tanah dan muka air tanah yang ekstrim.

- Penambahan sambungan umum di daerah pemukiman padat dan warganya mempunyai tingkat ekonomi rendah.
3. Diperlukan instrumen perundangan dan program pengendalian sumberdaya air tanah yang lebih menyentuh permasalahan yang actual, antara lain kebijakan perlindungan daerah tangkapan air diselatan Jakarta, yaitu daerah pegunungan (Gunung Salak, Gede dan Pangrango) maupun di daerah penggunaan air tanah terutama di wilayah JABODETABEK antara lain dengan cara :

- Memperketat persyaratan menebang pohon didaerah tangkapan air.

- Penyempurnaan SK Gubernur nomor 115 tahun 2001 sehingga diarahkan tidak hanya pemilik gedung baru, diperluas jangkauan sasaran kewajiban pembuatan sumur resapan yaitu tidak hanya pemilik bangunan baru di Jakarta saja akan tetapi meliputi seluruh warga JABODETABEK. Oleh karena itu untuk keperluan ini dibutuhkan kerjasama lintas propinsi.

- Sosialisasi secara menyeluruh melalui media masa cetak dan elektronik terhadap pedoman konservasi air tanah termasuk perlindungan daerah tangkapan air, cara cara pembuatan sumur resapan dll.

4. Perlu dilakukan kajian teknis secara lebih menyeluruh dan mendetail kemungkinan penerapan imbuhan buatan pada akuifer Jakarta, antara lain :

- Penyelidikan karakteristik tanah secara lebih detail yang meliputi porositas tanah, koefisien kelaluan hidrolis pada kawasan kritis.

- Kajian dan pemilihan teknologi yang paling tepat dalam implementasi teknik imbuhan buatan.

- Kajian secara kuantitatif dan kualitatif terhadap air baku yang akan disuntikkan.

- Kajian perlunya sistem purifikasi yang paling tepat terhadap air baku yang akan disuntikkan.

- Analisa mengenai dampak lingkungan di lokasi penyuntikan air.

\section{DAFTAR PUSTAKA}

1. Badan Pengendalian Lingkungan Hidup Daerah DKI Jakarta. 2004. Kebijakan dan Strategi Pemda DKI Jakarta Mengantisipasi Bencana Serta Dampak Kemarau dan Banjir. Lokakarya. Perubahan Iklim Bencana Alam di DKI Jakarta "Antisipasi dan Mitigasi Dampak Kemarau Banjir". Jakarta.

2. Bear, J. 1979. Hydraulic of Groundwater. McGraw-Hill. New York. 
3. Chang, J - H. 1968. Climate and Agriculture: An Ecological Survey. Aldine Publishing Co. Chicago:

4. Chiang, C.Y., M. F. Wheeler dan P.B. Bedient. 1989. A Method of Characteristics Technique and Mixed Finite Elements Method for Simulation of Groundwater Solute Transport. Water Resources Research. July 1989. Vol.25. No.7. 15411549.

5. Djajaputra, A. Aziz. 2001. Penurunan Muka Tanah dan Faktor Beban Permukaan Daerah Jakarta. Seminar Tinjauan Geologi Terhadap Daerah Genangan Di Wilayah D.K.I. Jakarta dari Faktor Penurunan Tanah Secara Non-Alami. 3 Mei 2001. Diselenggarakan oleh Laboratorium Mekanika Tanah Jurusan Teknik Sipil Universitas Indonesia dan Dinas Pertambangan Pemda DKI. Jakarta.

6. Dinas Pertambangan DKI Jakarta. 2000. Studi Pengaruh Pemompaan Air Bawah Tanah Terhadap Land Subsidence dan Intrusi Air Laut,

7. Direktorat Geologi Tata Lingkungan. Peta Hidrogeologi Indonesia. Lembar 1209-1. Bogor. Jawabarat. Disalin dari : Laporan Tahunan DGTL, 1994/1995.

8. Freeze, Allan R., John A. Cherry. 1979. Groundwater. Prentice Hall. Englewood Cliffs, New Jersey.

9. Fujioka, Yamaguchi. 1982. Pengamatan System Air Tanah Jakarta. Tinjauan Hidrogeologi Basin Jakarta.

10. Hadipurwo, Satryo dan Syamsul Hadi. 2000. Konservasi Air Tanah Daerah Jakarta - Bogor. Menyertai Peta Pengendalian Pengambilan Air Tanah. Direktorat Geologi Tata Lingkungan.

11. Havis, R.N., R.E. Smith, dan D. D. Adrian. 1992. Partitioning Solute Transport Between Infiltration and Overland Flow Under Rainfall. Water Resources Research.October 1992. Vol. 28, No. 10. 2569-2580.

12. Hutasoit, Lambok M. 2004. Hidrogeologi Cekungan Jakarta untuk Pengembangan Resapan Buatan. Laboratorium Simulasi Numerik Hidrogeologi. Departemen Teknik Geologi. ITB

13. IWACO, DHV Consultants, DELFT HYDRAULICS, TNO, PT. Indah Karya, PT. Kwarsa Hexagon, PT. Wiratman \& Associates. 1994. Jabotabek Water Resources Management Study. Directorate General of Water Resources Development. Ministry of Public Works. Government of Indonesia. Jakarta

14. McDonald, Adrian T., David Kay. 1988. Water Resources: Issues \& Strategies.
Themes in Resource Management. Longman Scientific \& Technical. John Wiley \& Sons. Inc. New York.

15. McDonald, Michael $T$ dan Allen $W$. Harbaugh. 1997. A Three - Dimensional Finite - Difference Groundwater Flow Model.

16. Indec \& Associates Ltd. 1987. Cisadane River basin development feasibility study. Final feasibility report. Main report. Vol.1. Jakarta. Indonesia

17. Indec \& Associates Ltd. 1987. Cisadane River Basin Development Feasibility Study. Final Feasibility Report. Groundwater. Vol.3. Jakarta. Indonesia.

18. Orange County Water District. 1999. Water Factory 21. http://www.ocwd.com

19. Puslitbang Teknologi Sumber Daya Air Departemen Pemukiman dan Prasarana Wilayah. 2000. Studi Banjir di Wilayah Kamal - Cengkareng - Kapuk. Propinsi DKI Jakarta.

20. Lindstrom, F.T. and W.T. Piver. 1991. Mathematical Models for Describing Transport in the Unsaturated Zone of Soil. The Handbook of Environmental Chemistry. Vol 5 Part A. Springer-Verlag. Berlin.

21. Pemerintah Daerah DKI Jakarta.2000. Agenda 21 Daerah Khusus Ibukota Jakarta.

22. Peta Geologi Tata Lingkungan Indonesia. 1996. Lembar: DKI Jakarta. Direktorat Geologi Tata Lingkungan. Bandung.

23. Rogers, Peter P. dan Myron B. Fiering. 1986. Use of Systems Analysis in Water Management. Water Resources Research. Vol. 22. No.9. Agustus 1986. Hal. 146s158s.

24. Samsuhadi. 1990. Optimal Control Of Saltwater Intrusion. Application For The Jakarta Groundwater Basin. Master's Thesis. Humboldt State University. Arcata. California.

25. Soeryantono, Herr, Dwita SK Marsudiantoro, Herlina. 2001. Pengendalian Keadaan Hidrogeologi untuk Mencegah Peningkatan Intensitas Spasial Genangan Air; Studi Kasus: Cekungan Air Tanah Jakarta di Sekitar Kampus UIDepok. Seminar Tinjauan Geologi Terhadap Daerah Genangan Di Wilayah D.K.I. Jakarta dari Faktor Penurunan Tanah Secara Non-Alami. 3 Mei 2001. Diselenggarakan oleh Laboratorium Mekanika Tanah Jurusan Teknik Sipil Universitas Indonesia dan Dinas Pertambangan Pemda DKI. Jakarta.

26. Soekardi, P. dkk. 1986. Geological Aspect of The Aquifer System and Groundwater 
Situation of The Jakarta Artesian Basin. Seminar of Geological Mapping in The Urban Development. Economic and Social Commision for Asia and The Pacific. Bangkok.

27. Taigbenu, Agpofure E, James A. Ligget dan Alexander H-D. Cheng. 1984. Boundary Integral Solution to Seawater Intrusion Into Coastal Aquifers. Water Resources Research. Vol.20.No.8. Agustus 1984. Hal.1150-1158.

28. Tambunan, Rudy P. 2005. Dampak Perkembangan Fisik Kota terhadap Pola Tata Air Ekosistem Dataran Rendah Jakarta. Disertasi. Jenjang Doktor Program Studi IImu Lngkungan. Program Pascasarjana. Universitas Indonesia.

29. Tucciarelli, Tullio dan George Pinder. 1991. Optimal Data Acquisition Strategy for The Development of a Transport Model for Groundwater Remediation. Water Resources Research. April 1991. Vol. 27. No.4. 577-588.

30. Vacher, H.L. 1988. Dupuit-GhybenHerzberg of Strip-Island Lenses. Geological Society of America Bulletin. Vol.100. April 1988. Hal 580-591

31. Waterloo Hydrologic. 1997. Visual MODFLOW.

32. Wanakule, Nisai dan Larry W. Mays. 1986. Optimal Management of Large Scale Aquifers Methodology and Application. Water Resources Research. Vol.22. No.4. April 1986. Hal. 446-465.

33. Wandowo. 2000. Teknologi Isotop Alam untuk Evaluasi Dinamika Aliran Air anah: Studi Daerah Resapan dan Intrusi Air Laut Akuifer Jakarta dan sekitarnya. Laporan akhir riset. Riset Unggulan Terpadu V. Bidang Teknologi Perlindungan Lingkungan (1997 - 2000). Puslitbang Tekinologi Isotop dan Radiasi Badan Tenaga Nuklir Nasional. Kantor Menteri
Negara Riset dan Teknologi. Dewan Riset Nasional. Jakarta

34. Willis, Robert. 1976. Optimal Groundwater Quality Management. Well Injection Of Waste Water. Water Resources Research. Vol.12. No. 1:47-53

35. Willis, Robert and William W-G. Yeh. 1987. Groundwater System Planning And Management. Prentice Hall. Englewood. New Jersey.

36. Willis, Robert and Brad A. Finney. 1988. Planning Model For Optimal Control Of Seawater Intrusion. Journal of Waters Resources Planning and Management. March, 1988, vol.114. No.2, Paper no.22258

37. Willis, Robert dan Philip Liu. 1984. Optimization Model for Groundwater Planning. Journal of Water Resources Planning and Management. Vol. 110. No.3. Hal 333-346.

38. Willis, Robert dan Brad Finney. 1985. Optimal Control of Nonlinear Groundwater Hydraulics: Theoretical Development and Numerical Experiments. Water Resources Research. Vol.21. No.10. Oktober 1985. Hal.1476-1482.

39. Willis, Robert. 1976. Optimal Groundwater Quality Management. Well Injection Of Waste Water. Water Resources Research. Vol.12. No. 1:47-53

40. Willis, Robert and William W-G. Yeh. 1987. Groundwater System Planning And Management. Prentice Hall. Englewood. New Jersey.

41. Yates, S. R. 1990. An Analytical Solution for One-Dimensional Transport in Heterogeneous Porous Media. Water Resources Research. October 1990. Vol. 26. No. 10.2331-2338. 